\title{
Changing Family Formation in Nepal: Marriage, Cohabitation and First Sexual Intercourse
}

\section{ByMarcantonio Caltabiano and Maria Castiglioni}

Marcantonio Caltabiano is reseacher and Maria Castiglioni is associate professor, both in the

Department of Statistical Sciences, University of Padova, Italy.
CONTEXT: In Nepal, marriage occurs at a relatively young age and arranged weddings are widespread. However, recent changes in the family formation process and the timing of first sexual intercourse suggest that a transformation may be under way.

METHODS: Data on marriage, cohabitation and first sexual intercourse from the 2001 Nepalese Demographic and Health Survey were used to describe the family formation process. The sequence of these events and the intervals between them were explored for currently married men and women. Hazard models were used to identify factors associated with behavioral changes over time.

RESULTS: The average age at marriage among women married before age 20 increased from 13.7 years for those born in 1952-1956 to 15.6 years for those born in 1977-1981, while remaining relatively stable for men married before age 25 (17.3 years for the 1942-1946 birth cohort to 17.7 for the 1972-1976 birth cohort). After individual and couple characteristics were controlled for, younger age at interview was associated with greater odds of simultaneous marriage and cohabitation for both genders (odds ratios, 1.3-1.7). Younger age at interview was also associated with premarital sex among men - those aged 39 or younger had significantly higher risks than older men of having had premarital sex, with odds ratios rising from 1.6 among those aged 35-39 to 1.8 among those aged 15-24.

CONCLUSIONS: It is important not only to promote education as a means of delaying marriage and childbearing, but also to implement programs and services that prevent reproductive health problems for young married couples. International Family Planning Perspectives, 2008, 34(1):30-39
In Nepal, as in other southern Asian countries, marriage is universal and occurs at a relatively young age. However, age at marriage celebration has increased. While women born in 1952-1956 married at the median age of 14.6 years, those born at the end of the 1970 s married at 16.5 years. ${ }^{1}$

This description, however, is somewhat incomplete, as in many Asian countries the marriage celebration, which marks the beginning of a conjugal union, often precedes actual cohabitation. Cohabitation may be delayed for months or even years for a variety of reasons, such as waiting for the bride to mature physically or waiting for housing to be made available. Consequently, to fully understand the process of family formation in Nepal, ${ }^{*}$ we must take age at cohabitation into consideration. The median age at first cohabitation has been rising slowly, but still remains below age 18 for women born in the early 1980s. ${ }^{2}$ Moreover, because age at first marriage has risen more quickly than age at first cohabitation, the interval between marriage and cohabitation has decreased. Men are also marrying at later ages, although for men born in 1942-1976, age at first cohabitation has remained more or less constant, at around age 20. ${ }^{3}$ Recently, however, signs of an increase in men's age at first cohabitation have begun to appear. ${ }^{2}$

*In the context of Nepal, this process consists of the marriage celebration, the beginning of cohabitation and the initiation of sexual intercourse.
Young age at marriage in Nepal is closely linked to the widespread practice of arranged marriages, where relationships and agreements between families prevail over individual choices. Thus, a decline in very early marriage, accompanied by a decrease in the interval between marriage and cohabitation, may indicate a change in the marital decision-making process and an increase in the level of involvement on the part of spouses in the formation of their own marital unions. ${ }^{4-6}$ Indeed, a number of recent studies have documented important transformations in Nepalese marital traditions.

For example, an analysis of data from the 1996 Chitwan Valley Family Survey, which was conducted in an area undergoing rapid social change in south central Nepal, showed the strong negative effects of three characteristicsschool enrollment, employment and having visited health care services-on the probability of ever marrying. ${ }^{7,8}$ Another study, using data from a survey conducted in Nepal in 2000 among 14-22-year-olds, concluded that later age at marriage is associated with greater involvement of young people in the marital decision-making process, as well as with urban residence and higher levels of educational attainment. ${ }^{4}$

A third study, using qualitative and quantitative data from a 2003 survey in the western Chitwan Valley, suggested that changing attitudes and behaviors toward mar- 
riage are a consequence of the diffusion of a new "developmental idealism."9 In other words, an increasing number of people believe that the "modern" family is both good and attainable, and find several aspects of western marriage desirable. Education of women seems to be the most powerful influence on attitudes toward marriage. ${ }^{9}$ More generally, shifting views result from changes in the socialization process. Young people who are educated, employed or exposed to media, have participated in youth clubs, have had nonfamily living experiences and have made residential moves appear to marry at an older age $e^{7,8}$ and to be more involved than other youth in the choice of their spouse. ${ }^{10}$ Socializing with others may raise aspirations and change behaviors. $7,8,11$

If it is true that individuals socialized in a more modern way have more freedom to choose their partners, we might expect to see change in the nature of relationships between couples. For example, people may modify their sexual behavior. ${ }^{5,12,13}$ If the social role of marriage as a contract between families weakens, then an increasing number of unions are likely to be formed on the basis of mutual decisions and love. Sex may become primarily an instrument of communication between the two partners rather than simply an instrument of procreation or a duty between spouses and may therefore play a more important role in the life of the couple. Eventually, sex may not require the legitimization of marriage.

In this study, we examine the process of family formation in Nepal for cohorts of men and women born in 1942-1981. We study the interactions between age at marriage, cohabitation and first sexual intercourse for males and females. Understanding recent changes in the family formation process and the timing of sexual initiation is fundamental to the design of successful government policies, programs and social interventions. Young age at cohabitation may put married couples at risk for reproductive health problems, while the postponement of marriage could lead young women and men to practice unsafe sex outside of stable relationships. ${ }^{14}$

\section{DATA AND METHODS}

In this paper, we analyze data from the 2001 Nepal Demographic and Health Survey (DHS). ${ }^{15}$ The survey collected data on the background characteristics of the respondents, as well as information on marriage, fertility, family planning, reproductive health and child health. The primary respondents were 8,726 ever-married women aged 15-49; 2,261 ever-married men aged 15-59 were also interviewed. Data for currently married men are lined with those of their wives. Information on age at first marriage and age at first cohabitation* with the partner was collected for all men and women who had ever been married and had cohabited. Basic data were also obtained about the members of each household (sex, age, highest level of education, marital status).

Although sexuality has recently gained attention because of concerns over health and STIs such as HIV, nationally representative information is still relatively scarce in the Asian context for both males and females. ${ }^{16}$ Nepal is the only country in southern Asia for which the DHS contains questions about the age at first sexual intercourse for males and females. ${ }^{\dagger}$ Information on age at first sexual intercourse was collected for all currently married individuals.

The main dependent variables in our analyses are age at first marriage celebration, first cohabitation and first sexual intercourse. Because these events are not always clearly identifiable and recognizable in developing countries, ${ }^{17,18}$ we follow the approach used by the DHS, which accepts respondents' definitions of marriage celebration, cohabitation and first sexual intercourse.

\section{Sequence of and Intervals Between Events}

Our description of the family formation process is based on the sequence of the following events: marriage, cohabitation and first sexual intercourse. As information on these events was collected only for currently married individuals who had cohabited, each respondent has experienced all three; however, differences appear in the order of and intervals between events. We are especially interested in whether these events occurred simultaneously or sequentially, and if the latter, the order in which they occurred and the duration of intervals between events. This perspective allows us to identify different types of sequences.

\section{Modeling}

We use regression analyses to determine if changes in behavior are more widespread among less traditional groups. We study the forces that accelerate or delay first cohabitation and sexual debut among men and women. We also examine the determinants of "love marriages" for both sexes (identified by simultaneous marriage and cohabitation) and of premarital sex for men. From the results of these analyses, we identify the individual determinants of change in the Nepalese family formation process.

The timing of cohabitation and sexual debut is studied using a discrete time event history approach, employing hazard models. We analyze the time from age 10 to first cohabitation and to sexual debut using hazard rate equations. ${ }^{19}$ The dependent variables are the probabilities of cohabiting and of experiencing first sexual intercourse. A covariate that significantly reduces the probability of experiencing an event (when the estimated odds ratios are less than 1.0) signifies that people with that characteristic delay the event under consideration. We do not consider the wife's characteristics in the analysis of men's sexual debut, because the increasing proportion of young men who are having premarital sex rarely do so with their future wife.

In total, the analysis included 7,732 married women aged 15-49 who had already begun to live with their partner. In

\footnotetext{
*These data were collected as completed years of age.

tOther comparative surveys on sexual behaviors in Asia, carried out in the late 1980 s and the 1990s on nationally representative samples (source:ref-
} erence 18), covered only a few countries and are now out of date. 


\begin{tabular}{|c|c|c|c|c|c|}
\hline Characteristic & $\begin{array}{l}\text { Females } \\
(N=7,732)\end{array}$ & $\begin{array}{l}\text { Males } \\
(\mathrm{N}=1,528)\end{array}$ & Characteristic & $\begin{array}{l}\text { Females } \\
(\mathrm{N}=7,732)\end{array}$ & $\begin{array}{l}\text { Males } \\
(\mathrm{N}=1,528)\end{array}$ \\
\hline \multicolumn{3}{|l|}{ Wife's age at interview } & \multicolumn{3}{|l|}{ Childhood residence } \\
\hline 15-19 & 11.9 & 10.4 & Countryside & 94.3 & 94.8 \\
\hline $20-24$ & 20.2 & 20.2 & Town & 4.5 & 4.2 \\
\hline $25-29$ & 19.6 & 17.8 & City & 1.2 & 1.0 \\
\hline $30-34$ & 16.4 & 17.2 & & & \\
\hline $35-39$ & 12.6 & 13.6 & Current residence & & \\
\hline $40-44$ & 10.9 & 11.0 & Central Hill (Kathmandu area) & 10.7 & 11.0 \\
\hline \multirow[t]{2}{*}{$45-49$} & 8.4 & 9.7 & Eastern Mountain & 1.4 & 1.4 \\
\hline & & & Central Mountain & 2.3 & 2.5 \\
\hline \multicolumn{3}{|c|}{ Husband's age at interview } & Western Mountain & 3.0 & 2.1 \\
\hline 15-19 & 3.0 & 3.4 & Eastern Hill & 6.5 & 7.1 \\
\hline $20-24$ & 14.3 & 15.5 & Western Hill & 12.4 & 9.0 \\
\hline $25-29$ & 18.9 & 17.8 & Midwestern Hill & 6.7 & 5.8 \\
\hline 30-34 & 18.2 & 17.4 & Far Western Hill & 4.2 & 3.9 \\
\hline 35-39 & 14.7 & 16.2 & Eastern Terai & 16.2 & 17.7 \\
\hline $40-44$ & 11.6 & 10.9 & Central Terai & 19.5 & 20.7 \\
\hline $45-49$ & 9.8 & 10.1 & Western Terai & 8.3 & 9.3 \\
\hline \multirow[t]{2}{*}{$50-59$} & $9.5^{*}$ & 8.5 & Midwestern Terai & 5.0 & 5.4 \\
\hline & & & Far Western Terai & 3.8 & 4.1 \\
\hline \multicolumn{6}{|c|}{ Wife's level of education } \\
\hline None & 82.4 & 83.5 & Ethnicity & & \\
\hline Primary & 13.4 & 12.2 & Hill-Brahman & 12.5 & 11.9 \\
\hline Secondary & 2.9 & 3.3 & Hill-Chhetri/Sanyashi/Thakuri & 17.6 & 15.9 \\
\hline \multirow[t]{2}{*}{ Higher } & 1.3 & 1.0 & $\begin{array}{l}\text { Hill-Newar } \\
\text { Hill-Gurung/Limbu/Magar/ }\end{array}$ & 5.0 & 5.1 \\
\hline & \multirow{2}{*}{\multicolumn{2}{|c|}{ Husband's level of education }} & Rai/Tamang & 18.0 & 17.3 \\
\hline $\begin{array}{l}\text { Husband's level of edu } \\
\text { sprimary }\end{array}$ & & & Hill-Marginal/Dalit & 9.0 & 7.8 \\
\hline \multirow[t]{2}{*}{$\geq$ secondary } & 16.1 & $\begin{array}{l}85.9 \\
14.1\end{array}$ & Hill-Mountain ethnic & & \\
\hline & & & $\begin{array}{c}\text { (Sherpa et al.) } \\
\text { Terai-Musalman }\end{array}$ & $\begin{array}{l}1.7 \\
48\end{array}$ & 2.6 \\
\hline \multicolumn{2}{|l|}{ Wife's age at marriage } & & Terai-Tharu/Danuwar/Dhimal/ & & \\
\hline$\leq 12$ & 14.5 & 5.6 & Majhi/Rajbanshi & 7.5 & 9.0 \\
\hline $13-14$ & 19.9 & 7.5 & Terai-Advantaged & 4.9 & 5.7 \\
\hline $15-16$ & 28.9 & 15.4 & Terai-Marginal & 10.6 & 11.7 \\
\hline $17-18$ & 18.6 & 21.8 & Terai-Others & 8.4 & 7.8 \\
\hline $19-20$ & 10.5 & 16.7 & & & \\
\hline \multirow[t]{2}{*}{$\geq 21$} & 7.6 & 33.0 & Religion & & \\
\hline & & & Hindu & 85.7 & 84.9 \\
\hline \multicolumn{3}{|c|}{ Age difference between spouses } & Other & 14.3 & 15.1 \\
\hline Wife $\geq 3$ years younger & 65.8 & 57.9 & & & \\
\hline Wife $0-2$ years younger & 27.8 & 31.0 & $\begin{array}{l}\text { Had premarital intercourse } \\
\text { Yes }\end{array}$ & & \\
\hline \multirow[t]{2}{*}{ Wife older } & 6.4 & 11.1 & $\begin{array}{l}\text { Yes } \\
\text { No }\end{array}$ & $\begin{array}{r}1.0 \\
99.0\end{array}$ & $\begin{array}{l}14.1 \\
85.9\end{array}$ \\
\hline & & & Total & 100.0 & 100.0 \\
\hline
\end{tabular}

*Includes some men older than 59. Note: Percentages may not total 100.0 because of rounding.

addition, we examined a sample of 1,528 married men aged 15-59 who also had already begun to live with their partner, and who had only one wife whose age fell between 15 and 49.* In order to include in our models some of the husband's or wife's characteristics, we limited the sample to women and men who had been married only once. The characteristics of the sample are shown in Table 1.

*Because we selected a subsample as our target population ( $73 \%$ of the total sample of females and $17 \%$ of the males), we included a probit equation to control for selectivity using the Heckman approach (source:Heckman JJ, Sample selection bias as a specification error, Econometrica, 1979 $47(1): 153-161)$. Basic information on all of the members of the sample households who were not selected for the individual interview was used to control for selectivity bias.

†Because we took only currently married people into consideration, the younger cohorts are censored at early ages at marriage. Consequently, the cohort parameters are overestimated because they measure the increased probability of cohabitation at young ages.
The selection of currently married respondents prohibits us from exploring changes in age at first cohabitation across cohorts. ${ }^{\dagger}$ However, in order to estimate the impact of cohort (and other covariates) on the probability of first cohabitation for females, we can apply hazard models to all of the women, considering never-married women as censored at interview. This is possible because first cohabitation in Nepal always follows the marriage celebration for females. In these models, we can introduce only the respondent's characteristics. We first estimated the birth-cohort effect to measure behavioral changes, and then introduced other covariates to see if they might explain these changes.

Finally, to illustrate the forces behind the increase in love marriages among men and women and premarital sex among men, we used probit regression models. In the 
model for love marriages, the dependent variable is the probability of simultaneous marriage and cohabitation (for both married women and men). Covariates for the wife and the husband are included in the models. In the model for premarital sex among married men, the dependent variable is the probability of having first sexual intercourse before the marriage celebration. Couple covariates were not considered.

\section{RESULTS}

\section{Sequence of Events}

In Nepal, the traditional behavior of delaying cohabitation was common among women born in the early 1950 s (more than 40\%), as well as among men born in 1947-1961 who were younger than 20 at marriage (45-53\%; Table 2). The frequency of this behavior has declined over time, involving only about $20 \%$ of the youngest married men and women. In each cohort, for both genders, this behavior was associated with younger age at marriage.

For almost all women, first sexual intercourse takes place within marriage. Only 1\% of women said that they had had premarital sex, regardless of whether or not they had delayed cohabitation (not shown). In the majority of cases, women's first sexual experience coincides with cohabitation (98\%; not shown).

Among men, the proportion who had first sexual intercourse after the marriage celebration but before cohabitation is only slightly higher than that among women (1.9\% vs. $0.2 \%$; not shown). The main difference between the two sexes is in the proportion who had had premarital sex. For men, this number is higher and is increasing. For example, among men who married and cohabited before age 20 , the proportion having premarital sex was $3 \%$ for the 1942-1946 cohort and 14\% for the 1977-1981 cohort. These percentages are higher among those who marry and cohabit at later ages-among men in the 1967-1971 cohort, $11 \%$ of men who cohabited before age 20 had had premarital sex, while this was true for $20 \%$ of those who cohabited before age 30 . It is worth noting that for men who have premarital sex, marriage and cohabitation tend to occur at the same time; only $2 \%$ delay cohabitation (not shown).

\section{Duration of Intervals}

Women's time before age 20 is divided three intervals: the time without any events; the time after marriage but before cohabitation and sexual intercourse; and the time between the end of the process (when marriage, cohabitation and sexual intercourse have occurred) and age 20 (Table 3).* The declining interval of time a woman spends between her initiation of marriage, cohabitation and sexual intercourse and her 20th birthday (interval MCS) reveals the steady increase in age at first marital cohabitation for fe-

*Three additional intervals (the time after sexual intercourse, but before marriage and cohabitation; the time after marriage and sexual intercourse, but before cohabitation; and a residual interval, such as time spent in premarital cohabitation) apply only to men.
TABLE 2. Of respondents who experienced marriage and cohabitation before age 20, 25 or 30, the percentage of women and men who delayed cohabitation and the percentage of men who had premarital sex, by cohort

\begin{tabular}{lllllll|rrr} 
Cohort & \multicolumn{3}{l}{ Delayed cohabitation } & & \multicolumn{3}{l}{ Had premarital sex } \\
\hline & \multicolumn{3}{l}{ Women } & \multicolumn{3}{l}{ Men } & & & \multicolumn{2}{l}{ Men } \\
& $<20$ & $<25$ & $<30$ & $<20$ & $<25$ & $<30$ & $<20$ & $<25$ & $<30$ \\
\hline $1942-1946$ & na & na & na & 34.2 & 33.8 & 32.9 & 2.8 & 7.6 & 8.0 \\
$1947-1951$ & na & na & na & 53.2 & 43.7 & 38.8 & 4.2 & 7.1 & 11.5 \\
$1952-1956$ & 44.0 & 41.6 & 41.4 & 42.2 & 37.3 & 35.1 & 4.0 & 5.4 & 7.6 \\
$1957-1961$ & 39.3 & 36.9 & 36.5 & 44.8 & 39.5 & 36.0 & 8.1 & 10.4 & 12.4 \\
$1962-1966$ & 37.0 & 33.5 & 33.0 & 34.7 & 31.5 & 28.7 & 11.2 & 13.8 & 17.0 \\
$1967-1971$ & 30.5 & 27.8 & 27.5 & 38.6 & 29.3 & 26.8 & 10.9 & 17.7 & 19.7 \\
$1972-1976$ & 31.3 & 27.5 & na & 31.4 & 24.1 & na & 9.0 & 17.1 & na \\
$1977-1981$ & 24.1 & na & na & 18.3 & na & na & 14.1 & na & na \\
\hline
\end{tabular}

Note: na=not applicable.

males. For example, for women born in the early 1950s, this interval was 4.5 years; for women born in the late 1970 s and early 1980s, it was 3.8 years. Viewed from the opposite end of the process, the increase in the time spent with no events (interval 0)-which ranged from 13.7 years for all women in the 1952-1956 cohort to 15.6 for those in the 1977-1981 cohort-means that the starting point of family formation is delayed. The time spent married before cohabiting (interval $\mathrm{M}$ ) is also declining-the decrease from 1.8 years for the 1952-1956 cohort to 0.6 years for the 1977-1981 cohort confirms the decrease shown in Table 2 in the proportion of marriages in which the spouses do not begin living together immediately after the ceremony. The delay of the marriage celebration is compensated for by both the decline in the interval between marriage and cohabitation and in the time spent in marital cohabitation before age 20 .

The increase in age at marriage and the decline in the time between marriage and cohabitation characterize the female sample as a whole, and may mask differences across subgroups of women. Consequently, we examined our data to determine whether the women who delayed cohabitation after marriage shared in these changes. Like women in the overall sample, women who delayed cohabitation married at later ages over time (interval 0)from 11.3 years for women in the 1952-1956 cohort to 12.9 years for those in the 1977-1981 cohort-although change occurred at a slower pace than it did in the overall sample. The interval between marriage celebration and co-

\begin{tabular}{|c|c|c|c|c|c|c|c|c|}
\hline \multirow[t]{2}{*}{ Cohort } & \multicolumn{4}{|c|}{ All women } & \multicolumn{4}{|c|}{ Women who delayed cohabitation } \\
\hline & 0 & M & MCS & Total & 0 & M & MCS & Total \\
\hline 1952-1956 & 13.7 & 1.8 & 4.5 & 20 & 11.3 & 3.9 & 4.8 & 20 \\
\hline 1957-1961 & 14.0 & 1.5 & 4.4 & 20 & 11.8 & 3.7 & 4.6 & 20 \\
\hline 1962-1966 & 14.4 & 1.2 & 4.3 & 20 & 11.8 & 3.6 & 4.6 & 20 \\
\hline 1967-1971 & 15.0 & 0.8 & 4.2 & 20 & 12.5 & 2.9 & 4.6 & 20 \\
\hline 1972-1976 & 15.2 & 0.9 & 4.0 & 20 & 12.5 & 3.1 & 4.4 & 20 \\
\hline 1977-1981 & 15.6 & 0.6 & 3.8 & 20 & 12.9 & 2.7 & 4.4 & 20 \\
\hline
\end{tabular}

Notes: Interval 0 represents time without any events; interval $\mathrm{M}$, the time after marriage but before cohabitation and sexual intercourse; and interval MCS, the time between marriage, cohabitation and sexual intercourse and age 20. 
TABLE 4. Average time (in years) spent in specific intervals until age 25 , for all men and for men who had premarital sex, by cohort

\begin{tabular}{|c|c|c|c|c|c|c|c|c|c|c|c|}
\hline \multirow[t]{2}{*}{ Cohort } & \multicolumn{6}{|c|}{ All men } & \multicolumn{5}{|c|}{$\begin{array}{l}\text { Men who had premarital } \\
\text { intercourse }\end{array}$} \\
\hline & 0 & $S$ & $M$ & MCS & Other & Total & 0 & $S$ & MS & MCS & Total \\
\hline 1942-1946 & 17.3 & 0.5 & 1.0 & 6.1 & 0.0 & 25 & 15.5 & 4.5 & 0.0 & 5.0 & 25 \\
\hline 1947-1951 & 16.5 & 0.3 & 1.6 & 6.5 & 0.1 & 25 & 16.6 & 3.6 & 0.0 & 4.8 & 25 \\
\hline 1952-1956 & 17.4 & 0.3 & 1.3 & 6.0 & 0.1 & 25 & 17.2 & 2.8 & 0.0 & 5.0 & 25 \\
\hline 1957-1961 & 17.3 & 0.5 & 1.1 & 5.9 & 0.2 & 25 & 16.8 & 3.3 & 0.0 & 4.8 & 25 \\
\hline 1962-1966 & 17.8 & 0.8 & 0.6 & 5.7 & 0.2 & 25 & 16.4 & 3.5 & 0.0 & 5.0 & 25 \\
\hline 1967-1971 & 17.6 & 0.8 & 0.6 & 6.0 & 0.1 & 25 & 16.7 & 3.9 & 0.0 & 4.4 & 25 \\
\hline 1972-1976 & 17.7 & 0.8 & 0.5 & 5.9 & 0.1 & 25 & 17.0 & 3.7 & 0.0 & 4.4 & 25 \\
\hline
\end{tabular}

Notes: Interval 0 represents time without any events; interval S, the time after sexual intercourse, but before marriage and cohabitation; interval $\mathrm{M}$, the time after marriage but before cohabitation and sexual intercourse; interval MS, the time after marriage and sexual intercourse, but before cohabitation; and interval MCS, the time between marriage, cohabitation and sexual intercourse and age 25 . Other represents residual intervals, such as time spent in premarital cohabitation.

habitation (interval M) also declined over time for women who delayed cohabitation, from 3.9 years for women in the 1952-1956 cohort to 2.7 years for those in the 1977-1981 cohort.

Among men, no change is evident in the age at which the transitions begin (represented by interval 0 ), which varies between 16.5 years and 17.8 years across cohorts in the overall sample (Table 4). The only sign of change in this respect is found in the occurrence of events before age 20: Among very young males, the age at which the transitions begin increased slightly over time, suggesting a slow abandonment of traditional behaviors (not shown). In addition, the MCS interval did not change across time for men. In other words, the age at first marital cohabitation remained relatively stable. Finally, whereas first sexual intercourse and cohabitation occurred at the same time for women, the time between those events rose from 0.5 years to 0.8 years across cohorts of men (interval S).

We also explored whether the subgroup of men who engaged in first sexual intercourse before marriage showed evidence of change in the timing of other behaviors across cohorts. For example, we explored whether the younger cohorts experienced first sexual intercourse earlier or married later. As Table 4 shows, however, no clear trend emerged. The interval before sexual intercourse (interval 0 ) rose by 1.7 years among older cohorts (between 19421946 and 1952-1956). This change, however, did not greatly change the timing of marriage across cohorts, because it was offset somewhat by a decrease in the time between first sex and marriage (interval S). Unlike men in the overall sample, men who had had premarital sex did not postpone cohabitation after the marriage celebration; the value for interval MS is consistently 0.0. Moreover, compared with men as a whole, they are older at first marriage and first cohabitation (interval MCS is shorter).

\section{Determinants of Age at First Sex and Cohabitation}

Because first sexual intercourse and cohabitation occur at the same time for women, the factors associated with the two experiences are practically the same-Table 5 . Women's educational attainment is negatively associated with their risks of first sex and first cohabitation. The odds of first intercourse decline from 0.6 among young women with a primary education to 0.2 among those with a higher education, while the odds of first cohabitation fall from 0.8 to 0.3 , relative to the odds among young women with no schooling. Both outcome variables are also negatively associated with the husband's level of education, and first cohabitation is negatively associated with the wife's age at marriage. In comparison with wives who are three or more years younger than their husband, those who are $0-2$ years younger and those who are older than their husband have decreased odds of first and 0.4) and of first cohabitation (0.8 and 0.5).

Compared with those who lived in rural areas as children, women who lived in cities as children have decreased odds of first cohabitation (odds ratio, 0.7). Women who currently live in the less developed western and mountain districts of Nepal have greater odds of first intercourse than women living in the Kathmandu area (1.3-1.5). Compared with those from the Brahman group, women in the some of the Terai ethnic groups have significantly higher risks of both first intercourse and cohabitation (1.2-2.0).

Young men's educational attainment is associated only with first intercourse: Those with a secondary or higher education have a significantly lower risk than those with primary schooling or less (odds ratio, 0.7). However, schooling's association with cohabitation is completely captured by the wife's level of education: Compared with men whose wives have no education, those whose wives have a primary education have odds of 0.7 and those whose wives have secondary schooling have even lower odds (0.4). The wife's age at marriage is negatively associated with the odds of cohabitation, which decline from 0.3 among men whose wives were aged 14-16 at marriage to 0.04 among those whose wives were 17 or older. Compared with men who married a woman who was three or more years younger, those whose wives were $0-2$ years younger and those whose wives were older had higher odds of cohabitation (8.9 and 16.9, respectively).

Having lived in the city rather than the country as a child was associated with reduced odds of cohabitation (odds ratio, 0.3). Currently residing in the Eastern Mountain or Eastern Hill was associated with reduced odds of both first intercourse and cohabitation (0.4-0.6); living in the Far Western Terai was associated with increased odds of first intercourse (1.6) and cohabitation (1.8). Compared with men from the Brahman group, those who were of Terai origin and those of Sherpa origin generally had higher odds of first sex and cohabitation (1.7-3.4). Having had premarital sex was associated with elevated odds of cohabitation (1.9); being non-Hindu was marginally associated with elevated odds of cohabitation (1.5).

In Table 6 (page 36), model 1 illustrates the changes among cohorts in age at first cohabitation, and confirms the results drawn from our descriptive analyses. Com- 
pared with women older than 40, women from all other cohorts had decreased odds of cohabitation at a given age, ranging from 0.7 to 0.9 . These cohort effects are partially explained by the diffusion of education: Relative to women with no education, those with any education had decreased odds of cohabitation (0.1-0.6); these odds decreased as level of education increased (Model 2).

We analyzed the probability of simultaneous marriage and cohabitation as a measure of the diffusion of love marriages (Table 7, page 36). Several individual and partner characteristics that delay age at cohabitation also affect the simultaneity of the two events. In a model that included only age at interview, the odds of simultaneous marriage and cohabitation rose as women's age declined (odds ratios, 1.4-1.7). When all other background variables were added, women with primary education had higher odds of simultaneous marriage and cohabitation than did women with no schooling (1.2); having had a secondary education was marginally associated with higher odds of simultaneous marriage and cohabitation compared with having had no schooling. The odds of the two events being simultaneous were higher for women who had married between the ages of 14 and 16 (4.3) and for those who had married at age 17 or older (8.8) than for women who had married when younger than 14. Compared with those who lived in the countryside, women raised in the city had elevated odds of entering marriage and cohabitation at the same time (1.3). Also, when compared with women whose husband had a primary education or no education, those whose husband had secondary education or higher had greater odds of the two events occurring simultaneously (1.2).

As was shown with women, younger age at interview was associated with greater odds of simultaneous marriage and cohabitation for men (odds ratios, 1.3-1.4) in the univariate model; in the full model, however, only the youngest men were significantly more likely to begin living with their spouse immediately after the marriage celebration (1.4). Men whose wife married when she was older than age 17 or between the ages of 14 and 16 had greater odds of the two events occurring simultaneously than men whose wife had married before age 14. Men whose wife was less than two years younger and those whose wife was older had lower odds of simultaneous marriage and cohabitation than those whose wife was three or more years younger.

We also explored the characteristics associated with premarital sex among men (Table 8, page 37). In a model that included only age at interview, men who were aged 39 or younger had significantly higher risks than men who were older of having had premarital sex, with odds ratios rising from 1.6 among those aged 35-39 to 1.8 among those aged 15-24. Findings were similar in the full model. In that model, men who had a secondary or higher education had greater odds of having had first sex before marriage than did men who had no education (odds ratio, 1.3).
TABLE 5. Odds ratios from event history hazard models to identify associations of first sexual intercourse and cohabitation with selected characteristics, according to gender

Characteristic

\begin{tabular}{ll|ll} 
Females & \multicolumn{2}{|l}{ Males } & \\
\hline First & Cohabitation & First & Cohabitation
\end{tabular}

\section{Wife's level of education}

None (ref)

Primary

Secondary

Higher

Husband's level of education

$\leq$ primary (ref)

$\geq$ secondary

Wife's age at marriage

$<14$ (ref)

$14-16$

$\geq 17$

Age difference between spouses

Wife $\geq 3$ years younger (ref)

Wife $0-2$ years younger

Wife older

\section{Childhood residence}

Countryside (ref)

Town

City

Current residence

Central Hill (Kathmandu area) (ref)

Eastern Mountain

Central Mountain

Western Mountain

Eastern Hill

Western Hill

Midwestern Hill

Far Western Hill

Eastern Terai

Central Terai

Western Terai

Midwestern Terai

Far Western Terai

Ethnicity

Hill-Brahman (ref)

Hill-Chhetri/Sanyashi/Thakuri

Hill-Newar

Hill-Gurung/Limbu/Magar/Rai/Tamang

Hill-Marginal/Dalit

Hill-Mountain ethnic (Sherpa et al.)

Terai-Musalman

Terai-Tharu/Danuwar/Dhimal/

Majhi/Rajbanshi

Terai-Advantaged

Terai-Marginal

Terai-Others

\section{Religion}

Hindu (ref)

Other

Had premarital intercourse

Yes (ref)

No

1.00

$\begin{array}{ll}1.00 & 1.00 \\ 0.64^{* *} & 0.84^{* *} \\ 0.31^{* *} & 0.61^{* *}\end{array}$

$0.17^{* *} \quad 0.25^{* *}$

1.00

$0.90+$

1.00

$0.89^{*}$

1.00

$0.69^{* *}$

1.00

na $\quad 1.00$

na $0.28^{* *}$

$0.28^{* *}$

na

$0.02^{* *}$

na

na

na

1.00

1.00

$0.70^{* *}$

$0.35^{* *}$

1.00
$0.84^{* *}$

0.50 **

1.00

0.90

$0.77 \dagger$

1.00

$1.18+$

$0.69^{*}$

1.00

0.85

0.51

1.00

0.89
$0.33^{*}$

1.00

$0.38^{* *}$

1.06

$1.46^{* *}$

$0.53^{* *}$

0.94

1.02

$1.62^{* *}$

$0.82^{*}$

$1.28^{* *}$

0.93

$1.30^{* *}$

$1.40^{* *}$

1.00

$0.38^{* *}$

$0.82^{*}$

0.87

$0.59^{* *}$

$0.71 * *$

0.85

1.02

0.86

1.19

$0.67^{* *}$

1.15

1.16

1.00

$0.49^{* *}$

0.96

$1.51 \dagger$

$0.60^{* *}$

0.75

1.14

$1.45+$

1.02

1.35

$1.43 \dagger$

1.17

$1.58^{*}$

1.00

$0.42^{* *}$

0.88

$0.55+$

$0.57^{*}$

0.90

1.27

1.54

1.18

$1.52 \dagger$

1.28

1.51

$1.76^{*}$

1.00

$0.82^{* *}$

$0.63^{* *}$

$0.71^{* *}$

$1.68^{* *}$

1.03

$1.16^{*}$

$1.43^{* *}$

0.92

1.99 **

$1.63^{* *}$

1.00

$1.18^{*}$

0.96

1.09

0.86

$1.18+$

$1.49^{* *}$

$0.72^{* *}$

$1.66^{*}$

0.90

$0.76^{* *}$

1.00

$1.42 *$

1.42
0.99

$1.48^{*}$

1.28

$3.39 * *$

$2.01^{* *}$

$1.73^{* *}$

$2.03 \dagger$

2.59 **

$1.97^{* *}$

1.00

1.32

1.40

$1.61^{*}$

0.63

$2.92^{* *}$

$2.38^{* *}$

1.16

1.13

$1.62+$

1.16

${ }^{*} p<.05 .{ }^{*} p<.01 .+p<.10$. Notes: All models control for the ages of the wife and the husband. The models also control for selection of married respondents and unobserved heterogeneity. ref=reference group. na=not applicable. 


\section{DISCUSSION}

In recent years, changes in family formation have become widespread in east and southeast Asia. Age at marriage for women is rising, as is the proportion of women who will never marry. Although the median age at marriage in Nepal is rising, it remains lower than that of other countries in the region. Our analysis builds on earlier studies by highlighting changes in the sequence of events and the intervals between them, and by identifying factors that influence the timing of transitions to cohabitation and first sexual intercourse in Nepal.

Our results show that the proportion of marriages with delayed cohabitation is declining for both males and females, while age at marriage celebration and cohabitation is increasing for females. Although marriages with delayed cohabitation are celebrated earlier than others, cohabitation is increasingly delayed, even by more traditional couples.

There are no signs that premarital sex is spreading among females, not even those marrying for love. In such cases, marriage celebration and cohabitation occur at the same time. This does not hold true for men, indicating that there is a double standard for sexual behavior in Nepal. For males who have premarital sex, sexual debut takes place 3-4 years before marriage. The proportion of young men having premarital sex has risen; that proportion varies little across regions and ethnic groups. However, fewer than 20\% of young males (born in the 1970s) practice this behavior, and there is no indication that these young men are engaging in nonmarital cohabitation. This is a rather small proportion compared with that observed in southern European countries, for example, where the double standard was common both before and during the sexual revolution. ${ }^{20}$

\section{Limitations}

Data on the characteristics of respondents during their adolescence and on their family and social context are not available in the DHS. Some of the most relevant individual and community factors that might be considered include female employment and other nonfamilial experiences, participation in the family decision-making process, vari-

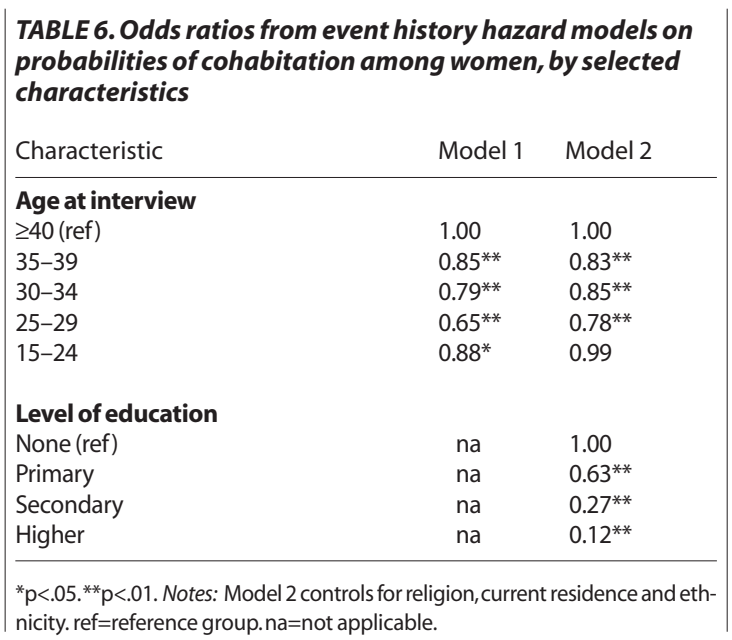

TABLE 7. Odds ratios from probit models identifying associations between selected characteristics and the probability of simultaneous cohabitation and marriage, by gender

Characteristic

\begin{tabular}{l|l} 
Females & Males \\
\hline Model 1 Model 2 & Model 1 Model 2
\end{tabular}

\begin{tabular}{l|l} 
Females & Males \\
\hline Model 1 Model 2 & Model 1 Model 2
\end{tabular}

Age at interview 35-49 (ref)

30-34

25-29

$15-24$

Wife's level of education

None (ref)

Primary

Secondary

Higher

\begin{tabular}{ll|ll}
1.00 & 1.00 & 1.00 & 1.00 \\
$1.40^{* *}$ & $1.21^{* *}$ & $1.29^{*}$ & 1.22
\end{tabular}

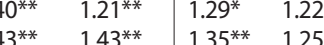

$\begin{array}{llll}71^{* *} & 1.68^{* *} & 1.39^{* *} & 1.40^{*}\end{array}$

Husband's level of education $\leq$ primary (ref)

$\geq$ secondary or higher

Wife's age at marriage

$<14$ (ref)

$14-16$

$\geq 17$

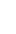

\begin{tabular}{ll|ll} 
& & & \\
na & 1.00 & na & 1.00 \\
na & $1.18^{*}$ & na & $1.68^{*}$ \\
na & $1.37 \dagger$ & na & 1.70
\end{tabular}

Age difference between spouses

Wife $\geq 3$ years younger (ref)

Wife $0-2$ years younger

Wife older

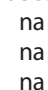

Childhood residence

Countryside (ref)

Town

City

\section{Current residence}

Central Hill (Kathmandu area) (ref)

Eastern Mountain

Central Mountain

Western Mountain

Eastern Hill

Western Hill

Midwestern Hill

Far Western Hill

Eastern Terai

Central Terai

Western Terai

Midwestern Terai

Far Western Terai

Ethnicity

Hill-Brahman (ref)

Hill-Chhetri/Sanyashi/

Thakuri

Hill-Newar

Hill-Gurung/Limbu/

Magar/Rai/Tamang

Hill-Marginal/Dalit

Hill-Mountain ethnic

(Sherpa et al.)

Terai-Musalman

Terai-Tharu/Danuwar/

Dhimal/Majhi/Rajbanshi

Terai-Advantaged

Terai-Marginal

Terai-Others

Religion

Hindu (ref)

Other

\begin{tabular}{ll|ll} 
na & 1.00 & na & 1.00 \\
na & 0.91 & na & $0.63^{* *}$ \\
na & $0.96 \dagger$ & na & $0.49^{* *}$ \\
& & & \\
& & & \\
na & 1.00 & na & 1.00 \\
na & 0.92 & na & 0.98 \\
na & $1.33^{*}$ & na & 1.40
\end{tabular}

${ }^{*} p<.05 .{ }^{* *} p<.01 .+p<.10 . \neq 35-59$ for males. §In this analysis, women with higher education were combined with women with secondary education. Notes: ref=reference group. na=not applicable. 
ous family systems and interfamilial relationships, and the payment of dowry. Female employment before marriage and other nonfamilial experiences and the increased autonomy that may result from these experiences could postpone family formation. ${ }^{78,10}$ However, the association of female employment with delayed marriage is unclear, especially in more traditional contexts, where families may use the woman's earnings for a dowry, increasing her marriageability. ${ }^{6}$ In some cases, female employment should be understood as a household strategy, because it frees her brothers and parents to conduct other activities outside the village. $^{21}$

The decision-making process can affect age at marriage, as arranged marriages tend to take place at younger ages than love marriages. In addition, the proportion of love

\begin{tabular}{|c|c|c|}
\hline Characteristic & Model 1 & Model 2 \\
\hline \multicolumn{3}{|l|}{ Age at interview } \\
\hline $45-59$ (ref) & 1.00 & 1.00 \\
\hline $40-44$ & 1.09 & 1.04 \\
\hline $35-39$ & $1.59^{* *}$ & $1.54^{* *}$ \\
\hline $30-34$ & $1.64^{* *}$ & $1.59^{* *}$ \\
\hline $25-29$ & $1.75^{* *}$ & $1.65^{* *}$ \\
\hline $15-24$ & $1.84^{* *}$ & $1.71^{* *}$ \\
\hline \multicolumn{3}{|l|}{ Level of education } \\
\hline None (ref) & na & 1.00 \\
\hline Primary & na & 1.09 \\
\hline$\geq$ secondary & na & $1.28^{*}$ \\
\hline \multicolumn{3}{|l|}{ Childhood residence } \\
\hline Countryside (ref) & na & 1.00 \\
\hline City or town & na & 1.10 \\
\hline \multicolumn{3}{|l|}{ Current residence } \\
\hline Central Hill (Kathmandu area) (ref) & na & 1.00 \\
\hline Eastern Mountain & na & 0.84 \\
\hline Central Mountain & na & 0.82 \\
\hline Western Mountain & na & 1.19 \\
\hline Eastern Hill & na & 0.92 \\
\hline Western Hill & na & $0.71 \dagger$ \\
\hline Midwestern Hill & na & 1.04 \\
\hline Far Western Hill & na & 0.95 \\
\hline Eastern Terai & na & 0.97 \\
\hline Central Terai & na & 0.86 \\
\hline Western Terai & na & 0.84 \\
\hline Midwestern Terai & na & 0.87 \\
\hline Far Western Terai & na & 1.08 \\
\hline \multicolumn{3}{|l|}{ Ethnicity } \\
\hline Hill-Brahman (ref) & na & 1.00 \\
\hline Hill-Chhetri/Sanyashi/Thakuri & na & 1.20 \\
\hline Hill-Newar & na & $0.67 \dagger$ \\
\hline Hill-Gurung/Limbu/Magar/Rai/Tamang & na & 1.17 \\
\hline Hill-Marginal/Dalit & na & 0.75 \\
\hline Hill-Mountain ethnic (Sherpa et al.) & na & 1.27 \\
\hline Terai-Musalman & na & $1.35 t$ \\
\hline \multicolumn{3}{|l|}{ Terai-Tharu/Danuwar/Dhimal/ } \\
\hline Majhi/Rajbanshi & na & 1.22 \\
\hline Terai-Advantaged & na & 1.05 \\
\hline Terai-Marginal & na & 1.15 \\
\hline Terai-Others & na & 1.00 \\
\hline \multicolumn{3}{|l|}{ Religion } \\
\hline Hindu (ref) & na & 1.00 \\
\hline Other & na & 0.94 \\
\hline
\end{tabular}

marriages increases with age at marriage, and the changes in marriage patterns are related to the diminishing number of arranged marriages. ${ }^{4,6}$

Social and economic changes affect the context in which marital decisions take place. For example, a modern community may be more open to accepting individuals' freedom to choose their spouse. ${ }^{11,22}$ Changes in family formation are also closely related to changes in family systems. Early marriage is typical in a society where the wedding serves as an alliance between families. In addition, the younger the prospective wife, the more malleable and submissive she will most likely be to the family rules and the authority of her new husband and in-laws. Very early marriage also prevents premarital sexual activity and protects against social censure of an unmarried daughter. ${ }^{6,21-24}$ Parental characteristics may also reflect a more or less modern family context. For example, an association has been found between higher educational attainment for fathers and mothers and lower probabilities of early marriage for their daughters. ${ }^{4,7,8}$

The payment of dowry plays a central role in arranged weddings and marriage patterns in Asian countries. In India, for example, the need for a dowry can delay a daughter's marriage until the parents have saved enough money. Some researchers, however, argue that parents may also accelerate the timing of the wedding to avoid the higher demands made for the dowry of older brides.

The quality of the data available in the DHS may also affect our results. One of the principal issues is the respondents' self-reports of the stages of family formation. Although our analysis is based on their responses, we do not know if these stages hold the same meaning for all respondents. However, our analysis is useful for at least four reasons. First, our analysis concerns only one country, thus making a contribution to understanding current trends within a common culture. Second, the existence of important changes in cohort behaviors is better demonstrated through analyses of sequences and intervals rather than the analysis of a specific event, such as marriage only or cohabitation only. Our results are a preliminary response to Hull and Hull's recommendation that "Retrospective studies in the future should pay particular attention to the issue of delay in consummation and cohabitation, and should also attempt to gather information on the various relevant stages of marriage, rather than asking only the age at marriage without regard to traditional patterns of arrangement and recognition of unions." ${ }^{17}$ Indeed, the timing of marriage is not a mere demographic event, but is part of a process within wider strategies of social reproduction. ${ }^{21}$ Third, our results are in keeping with those of in-depth studies such as the survey (mentioned earlier) on young Nepalese adults, where an emphasis was placed on the meanings of marriage transitions. And finally, our analysis demonstrates that research on this topic would be enhanced by the inclusion in surveys of additional questions concerning male and female transitions to adulthood, especially in the Asian context. 
A second related problem with the quality of the DHS data is the reliability of the self-reported age at the time of certain events. The main difference between males and females in our analysis lies in the timing of their sexual debut, but this result is dependent on honest answers concerning first sexual intercourse. In a society such as Nepal's, which has strong social control and rigid norms concerning female behavior, women may underreport certain events. ${ }^{16}$

\section{Policy Implications}

Our results suggest that one of the most important mechanisms for the raising age at marriage for males and females is the diffusion of education. However, attaining widespread delays in family formation through education may take many years. In the meantime, it is important to implement and reinforce programs and services that prevent reproductive health problems for young married couples. ${ }^{25}$ Our results help to identify the groups most likely to marry early: less educated people, those living in rural areas and those in the Terai and western regions.

Although our results show no evidence that delayed marriage currently entails an increase in risky sexual behavior on the part of young women, they do show that about one in five young men engage in premarital sex. These young men tend to initiate sex nearly four years before they marry and begin living with their wife, potentially exposing themselves to the risk of HIV and other STIs. Consequently, preventive health programs should address the risks of STIs with young unmarried men who have premarital sex and young married couples in which the husband has had premarital sexual experiences.

Our results show that it is not only factors related to modernization (such as education, socialization in urban areas and age balance between partners) that explain differences in age at family formation, but social characteristics as well (such as ethnicity and region of residence). This is also in line with results from previous studies. ${ }^{26,27}$ Consequently, programs that encourage marriage postponement will be successful only if they are contextualized within particular ethnic institutions and social settings. This means that policies should take regional differences into consideration and recognize that many actors are involved. Services to individuals must meet their special needs and distinct situations, and a particular effort should be made to include male partners in family interventions. In addition, the staff in service centers must be adequately trained, and parents and community members should be informed of the consequences of early marriages and births, and the advantages of postponing family formation. Finally, mass media (especially the radio) may provide a useful instrument through which to reach the entire target population. ${ }^{28,29}$

\section{REFERENCES}

1. Paladini V, Cambiamenti della formazione familiare in Nepal; matrimonio, convivenze e primo rapporto sessuale, unpublished thesis, Padua, Italy: Department of Statistical Sciences, University of Padua, 2005.
2. Ministry of Health and Population (MOHP), New ERA and Macro International, Nepal Demographic and Health Survey, 2006, Kathmandu, Nepal: MOHP, New ERA and Macro International, 2007.

3. Westoff CF, Trends in Marriage and Early Childbearing in Developing Countries, DHS Comparative Reports, Calverton, MD, USA: ORC Macro, 2003, No. 5

4. Choe MK, Thapa S and Mishra V, Early marriage and early motherhood in Nepal, Journal of Biosocial Sciences, 2005, 37(2):143-162.

5. Rindfuss RR and Morgan SP, Marriage, sex and the first birth interval: the quiet revolution in Asia, Population and Development Review, 1983, 9(2):259-278.

6. Caldwell B, Factors affecting female ages at marriage in South Asia, paper presented at the XXV International Union for the Scientific Study of Population International Population Conference, Tours, France, July 18-23, 2005.

7. Yabiku ST, Marriage timing in Nepal: organizational effects and individual mechanisms, Social Forces, 2004, 83(2):559-586.

8. Yabiku ST, The effect of non-family experiences on age of marriage in a setting of rapid social change, Population Studies, 2005 59(3):339-354

9. De Jong JAJ, Ghimire DJ and Thornton A, The influence of developmental idealism on marriage: evidence from Nepal, paper presented at the annual meeting of the Population Association of America, Los Angeles, CA, USA, Mar. 30-Apr. 1, 2006

10. Ghimire DJ et al., Social change, premarital nonfamily experience and spouse choice in an arranged marriage society, American Journal of Sociology, 2006, 111(4):1181-1218.

11. Yabiku ST, Neighbors and neighborhoods: effects on marriage timing, Population Research and Policy Review, 2006, 25(4):305-327.

12. Basu AM, Cultural influences on the timing of first births in India: large differences that add up to little differences, Population Studies, 1993, 47(1):85-95.

13. Fricke $T$ and Teachman JD, Writing the names: marriage style, living arrangements, and first birth interval in a Nepali society, Demography, 1993, 30(2):175-188.

14. Mukuria A, Aboulafia C and Themme A, The Context of Women's Health: Results from the Demographic and Health Surveys, 1994-2001, DHS Comparative Reports, Calverton, MD, USA: ORC Macro, 2005. No. 11.

15. MOHP, New ERA and ORC Macro, Nepal Demographic and Health Survey, 2001, Calverton, MD, USA: ORC Macro, 2002.

16. Xenos P et al., The timing of union formation and sexual onset: Asian evidence from young adult reproductive health surveys, EastWest Center Working Papers, Population Series, Honolulu, HI, USA East-West Center, 2001, No. 108

17. Hull TH and Hull VJ, Changing marriage behavior in Java: the role of timing of consummation, Southeast Asian Journal of Social Science, 1987, 15(1):104-119.

18. Cleland J and Ferry B, eds., Sexual Behavior and AIDS in the Developing World, Bristol, PA, USA: World Health Organization (WHO) and Taylor \& Francis, 1995.

19. Blossfeld HP and Rohwer G, Techniques of Event History Modelling New Approaches to Causal Analysis, Mahwah, NJ, USA: Lawrence Erlbaum Associates, 1995

20. Dalla Zuanna G, De Rose A and Racioppi F, Low fertility and limited diffusion of modern contraception in Italy during the second half of the twentieth century, Journal of Population Research, 2005, 22(1): 21-48.

21. Dahal DR, Fricke T and Thornton A, The family contexts of marriage timing in Nepal, Ethnology, 1993, 32(4):305-323.

22. Niraula BB and Morgan SP, Marriage formation, post-marital contact with natal kin and autonomy of women: evidence from two Nepali settings, Population Studies, 1996, 50(1):35-50

23. Gray JN, Marriage and the constitution of hierarchy and gender in Bahun-Chetri households, Contributions to the Nepalese Studies, 1991, 


\section{8(1):53-82}

24. Fricke T, Axinn WG and Thornton A, Marriage, social inequality and women's contact with their natal families in alliance societies: two Tamang examples, American Anthropologist, New Series, 1993, 95(2): 395-419.

25. Clark S, Bruce J and Dude A, Protecting young women from HIV/AIDS: the case against child and adolescent marriage, International Family Planning Perspectives, 2006, 32(2):79-88.

26. Thapa S, Girl child marriage in Nepal: its prevalence and correlates, Contributions to Nepalese Studies, 1996, 23(2):361-375.

27. Thapa S, Timing of family formation in ethnic mosaic Nepal: a district-level analysis, Asia-Pacific Population Journal, 1997, 12(2):7587.

28. Adhikari RH, Early marriage and childbearing: risks and consequences, in: WHO, Towards Adulthood: Exploring the Sexual and Reproductive Health of Adolescents in South Asia, Geneva: WHO, 2003.

29. Adhikari RH, Soonthorndhada K and Prasartkul P, Determinants of unintended pregnancy among currently pregnant married women in Nepal, paper presented at the biennial conference of the European Association of Population Scientists, Liverpool, UK, June 21-24, 2006.

\section{RESUMEN}

Contexto: En Nepal, el matrimonio ocurre a una edad relativamente temprana y los matrimonios arreglados están generalizados. Sin embargo, cambios recientes en el proceso de formación de la familia y el momento de la primera relación sexual, sugieren que puede estar ocurriendo una transformación.

Métodos: Se utilizaron los datos sobre matrimonio, cohabitación y primera relación sexual de la Encuesta de Demografía y Salud de Nepal de 2001, para describir el proceso de formación de la familia. La secuencia de estos eventos y los intervalos entre ellos fueron explorados para hombres y mujeres actualmente casados. Se utilizó modelos de riesgo para identificar factores asociados con cambios de conducta en el tiempo.

Resultados: La edad al matrimonio ha aumentado de 13.7 años para mujeres nacidas en 1952-1956 a 15.6 años para las nacidas en 1977-1981, mientras que ha permanecido relativamente estable para los hombres (17.3 años para la cohorte nacida en 1942-1946 a 17.7 para la cohorte nacida en 1972-1976). Después de controlar las características individuales y de pareja, se asoció una menor edad en el momento de la entrevista con mayores probabilidades de matrimonio y cohabitación simultáneos para ambos géneros (razones de momios, 1.3-1.7). La menor edad al momento de la entrevista también se asoció con las relaciones sexuales premaritales en los hombres: aquellos en edades de 39 años o menores tuvieron riesgos significativamente más altos de haber tenido relaciones sexuales premaritales que los hombres mayores, con razones de momios que variaban de 1.6 en los hombres de 35-39 años, a 1.8 en aquellos de 15-24 años.

Conclusiones: Es importante promover la educación como medio de retrasar el matrimonio y la maternidad. También se debe implementar programas y servicios orientados a prevenir problemas de salud reproductiva para los jóvenes casados.

\section{RÉSUMÉ}

Contexte: Au Népal, le mariage intervient à un âge relativement jeune et est souvent arrangé. De récentes évolutions $d u$ processus de formation de la famille et du moment des premiers rapports sexuels laissent toutefois entendre une transformation possible de la situation.

Méthodes: Les données relatives au mariage, à la cohabitation et aux premiers rapports sexuels issues de l'Enquête démographique et de santé népalaise de 2001 ont servi à décrire le processus de formation des familles. La séquence de ces événements et les intervalles qui les séparent ont été examinés pour les hommes et les femmes mariés. Des modèles de risque ont permis d'identifier les facteurs associés aux changements comportementaux dans le temps.

Résultats: L'âge au moment du mariage est passé de 13,7 ans pour les femmes nées en 1952-1956 à 15,6 ans pour celles nées en 1977-1981. Il est resté relativement stable pour les hommes (17,3 ans pour ceux de la cohorte de naissance de 1942-1946 à 17,7 pour ceux de la cohorte 1972-1976). Sous contrôle des caractéristiques individuelles et de couple, l'âge moindre au moment de l'entrevue s'est révélé associé à une probabilité plus élevée de mariage et cohabitation simultanés dans les deux sexes (rapport de probabilités, 1,3-1,7). Il est également apparu lié aux rapports sexuels prénuptiaux chez les hommesceux âgés de 39 ans ou moins présentent un risque significativement plus élevé que leurs aînés d'avoir eu des rapports prénuptiaux, les rapports de probabilités passant de 1,6 dans la tranche de 35 à 39 ans à 1,8 dans celle de 15 à 24 ans.

Conclusions: Il importe non seulement de promouvoir l'éducation comme moyen de différer le mariage et la procréation, mais aussi de mettre en ouvre des programmes et des services de prévention des problèmes de santé génésique pour les jeunes couples mariés.

\section{Acknowledgment}

The authors would like to thank Tiziana Leone for her helpful comments.

Author contact: mcalt@stat.unipd.it 